\title{
EVALUASI PERIODE PEMBERIAN PAKAN MENGANDUNG DAUN KAYU MANIS Cinnamomum burmannii TERHADAP KUALITAS DAGING IKAN NILA Oreochromis niloticus
}

\author{
Triana Retno Palupi, Mia Setiawati*, Dedi Jusadi, Ichsan Ahmad Fauzi, Wasjan
}

Departemen Budidaya Perairan, Fakultas Perikanan dan Ilmu Kelautan, Institut Pertanian Bogor, Kampus IPB Dramaga, Jalan Agatis, Telepon 0251 8622909-8622906, Bogor-Jawa Barat 16680.

^Korespondensi: miasetia@apps.ipb.ac.id

Diterima: 31 Desember 2019/ Disetujui: 30 April 2020

Cara sitasi: Palupi TR, Setiawati M, Jusadi D, Fauzi IA, Wasjan. 2020. Evaluasi periode pemberian pakan mengandung daun kayu manis Cinnamomum burmannii terhadap kualitas daging ikan nila Oreochromis niloticus. Jurnal Pengolahan Hasil Perikanan Indonesia. 23(1): 178-185.

\begin{abstract}
Abstak
Tekstur dan aroma menjadi salah satu indikator kualitas filet ikan nila untuk diekspor. Salah satu upaya untuk meningkatkan kualitas filet ikan dapat dilakukan dengan pemberian tepung daun kayu manis pada pakan. Penelitian ini bertujuan untuk menentukan periode waktu pemberian tepung daun kayu manis (DKM) yang dapat meningkatkan kualitas daging dan pertumbuhan ikan nila. Dosis tepung daun kayu manis yang diberikan pada adalah $1 \%$. Pakan diberikan selama 15 hari (15D), 30 hari (30D), 45 hari (45D) dan 60 hari (60D) sebelum panen. Pemeliharaan ikan dilakukan menggunakan 20 hapa berukuran 2x1x1,5 $\mathrm{m}^{3}$ dengan padat tebar 20 ekor ikan/hapa, bobot ikan $30,23 \pm 0,15 \mathrm{~g} /$ ekor dan panjang 11-13 cm/ekor. Hasil penelitian menunjukkan bahwa pemberian tepung DKM mampu meningkatkan kualitas tekstur daging ikan nila dengan perlakuan terbaik pada 30D dengan nilai 547,5 99,1 gf. Uji kinerja pertumbuhan bobot dan retensi protein perlakuan 60D memberikan nilai yang berbeda nyata dibanding kontrol dengan nilai $3.854,3 \pm 219,0 \mathrm{~g}$ dan 44,0 $\pm 6,3 \%$. Nilai glikogen hati menunjukkan semua perlakuan memberikan nilai yang berbeda nyata dibanding kontrol dengan nilai berturut-turut $0,33 \pm 0,01,0,35 \pm 0,01,0,35 \pm 0,00$, dan $0,35 \pm 0,00\left(\mathrm{mg} \mathrm{g}^{-1}\right)$. Nutrien berupa protein, lemak dan kadar air paling baik ditunjukkan pada perlakuan 60D dengan nilai masing-masing $18,8 \pm 0,7 \%, 1,85 \pm 0,14 \%$, dan $76,6 \pm 0,9 \%$. Berdasarkan hasil penelitian, dapat disimpulkan bahwa pemberian pakan mengandung daun kayu manis selama periode waktu 30 hari memberikan kualitas kekerasan daging ikan paling tinggi.
\end{abstract}

Kata kunci: daun kayu manis, kualitas daging, nutrien, pakan, tekstur

\section{Evaluation of Feeding Period Contain Cinnamon Leaf Flour Cinnamomum burmannii on The Meat Quality of Tilapia Oreochromis niloticus}

\begin{abstract}
Texture and aroma are indicators of fish fillets quality for export. Improving the quality of the fish fillet can be done by giving cinnamon leaf flour into the fish feed. This study was aimed to determine the period of cinnamon leaf flour (CLF) administration that can improve the meat quality and growth rate of tilapia. The dose of the cinnamon leaf flour in the feed was $1 \%$ and was fed for 15 days (15D), 30 days (30D), 45 days (45D) and 60 days (60D) before harvesting. The fish was maintained in 20 cages $(2 \times 1 \times 1.5 \mathrm{~m} 3)$ with stocking density about $20 \mathrm{fish} / \mathrm{cage}$. The initial body weight was $30.23 \pm 0.15 \mathrm{~g}$ and length $11-13 \mathrm{~cm}$. The administration of cinnamon leaf flour improved the texture with the best treatment on $30 \mathrm{D}$ with a value of $547.5 \pm 9.1 \mathrm{gf}$. The weight growth performance and protein retention of the $60 \mathrm{D}$ treatment were significantly higher compared to that of control with value of $3,854.3 \pm 219.0 \mathrm{~g}$ and $44.0 \pm 6.3 \%$, respectively. Liver glycogen levels of the fish from all feeding periods were significantly higher than from the control with the value of $0.33 \pm 0.01,0.35 \pm 0.01,0.35 \pm 0.00$, and $0.35 \pm 0.00 \mathrm{mg} \mathrm{g}^{-1}$, respectively. Proximate test result of the protein, fat and moisture was best showed in the $60 \mathrm{D}$ treatment with values of $18.8 \pm 0.7 \%, 1.85 \pm 0.14 \%$, and $76.6 \pm 0,9 \%$, respectively. Based on these results, it can be concluded that the feed containing cinnamon leaf with feeding period more than 30 days provides the best quality of tilapia meat texture.
\end{abstract}

Keywords: cinnamon burmannii, meat texture, nutrient, tilapia, texture 


\section{PENDAHULUAN}

Filet ikan nila menjadi produk perikanan unggulan keenam yang paling banyak diimpor Amerika (GAR 2015). Tahun 2017, Indonesia mengekspor filet beku ikan nila sebanyak 16.000 ton dan meningkat menjadi 19.000 ton pada tahun 2018 (FAO 2018). Ikan yang diperoleh dari perikanan tangkap memiliki kualitas daging yang lebih kompak dengan kadar lemak yang lebih rendah dibandingkan dengan ikan budidaya. Kualitas filet meliputi tekstur dan aroma ikan menjadi indikator filet untuk diekspor (Jusadi et al. 2016). Salah satu upaya untuk peningkatan tekstur daging ikan budidaya dapat dilakukan dengan menambahkan tepung daun kayu manis, seperti yang telah dilakukan pada ikan patin (Laheng et al. 2016; Setiawati et al. 2017).

Sinamaldehid merupakan senyawa utama yang terdapat di dalam minyak atsiri daun kayu manis (Khazanah et al. 2017). Sinamaldehid mampu mengaktifkan insulinlike growth factor yang dapat meningkatkan biosintesis protein dan kolagen sehingga meningkatkan deposisi protein dalam tubuh untuk membentuk daging (Takasao et al. 2012).

Jusadi et al. (2016) melaporkan bahwa pemberian tepung daun kayu manis $1 \%$ pada ikan mas selama 37 hari mampu memberikan kualitas daging yang kompak dan rasa yang lebih manis. Lebih lanjut penelitian yang dilakukan Laheng et al. (2016) menyatakan bahwa pemberian $1 \%$ tepung daun kayu manis pada ikan patin mampu meningkatkan laju pertumbuhan harian, efisiensi pakan, dan retensi protein masing-masing 24$29 \%$, 40-46\%, dan 56-67\% serta dapat menurunkan kadar lemak tubuh 10-12\% dan menurunkan lemak daging hingga 37-50\%. Penelitian dengan penambahan tepung daun kayu manis pada ikan nila telah dilakukan Ahmad et al. (2011) yang menyebutkan bahwa penambahan $1 \%$ tepung kayu manis selama 90 hari pada pakan ikan nila dapat meningkatkan pertumbuhan, meningkatkan survival rate (SR), menurunkan feed convertion ratio (FCR) dan meningkatkan apparent protein utilization (APU). Penambahan tepung daun kayu manis menyebabkan bertambahnya biaya produksi. Penelitian ini bertujuan untuk menentukan periode waktu pemberian tepung daun kayu manis yang tepat yang dapat meningkatkan kualitas daging dan pertumbuhan ikan nila.

\section{BAHAN DAN METODE Bahan dan Alat}

Bahan yang digunakan dalam penelitian ini adalah ikan nila merah, tepung daun kayu manis, pakan ikan komersil, putih telur untuk coating pakan, bahan kimia untuk proksimat. Alat yang digunakan Texture analyzer tipe TAxt2i Surrey-England, Chromameter CR-400 (Kinoca Minolta Japan), oven (WTB Binder tipe Fd 115), mixer (Philip), timbangan digital (China OEM tipe SF-400C), hapa/jaring berukuran $3 \times 2 \times 1,5 \mathrm{~m}^{3}$, neraca digital (OHAUS dengan ketelitian 0,0001 gram), centrifuge (Labnet tipe C0336), dan stirrer (JoanLab tipe SH-02).

\section{Metode Penelitian \\ Pembuatan pakan uji}

Pakan uji yang digunakan adalah pakan komersial dengan penambahan tepung daun kayu manis ke dalam pakan yang dilakukan secara coating, yaitu dengan mencampurkan air $(100 \mathrm{~mL})$, tepung daun kayu manis (1\% $\mathrm{kg}^{-1}$ pakan), telur 1 butir dan pakan ikan komersial. Pakan yang sudah tercampur rata, kemudian di oven dengan suhu $60^{\circ} \mathrm{C}$ selama 4 jam. Pakan untuk perlakuan kontrol tanpa penambahan tepung daun kayu manis.

\section{Pemeliharaan ikan}

Pemeliharaan ikan nila merah dilakukan dengan menggunakan 20 hapa berukuran $3 \times 2 \times 1,5 \mathrm{~m}^{3}$ dengan padat tebar 20 ekor ikan/hapa dengan bobot ikan $30,23 \pm 0,15 \mathrm{~g} /$ ekor dan panjang 11-13 cm/ekor. Bibit ikan diadaptasikan selama satu minggu, diberi pakan komersial tanpa perlakuan dengan frekuensi pemberian pakan dua kali sehari. Setelah satu minggu, ikan dipuasakan selama 24 jam untuk menghilangkan pengaruh sisa pakan di dalam saluran pencernaan, kemudian dilakukan penimbangan bobot awal ikan nila. Bibit ikan tersebut kemudian diberi pakan sesuai perlakuan, tanpa penambahan daun kayu manis (DKM) (control), pemberian DKM 15 hari (15D), 30 hari (30D), 45 hari (45D) dan 60 hari (60D) sebelum panen. 


\section{Prosedur Analisis} Feed intake (FI)

Perhitungan feed intake (FI) pakan dihitung dengan menghitung jumlah pakan yang dikonsumsi selama masa pemeliharaan. Feeding intake dapat dihitung menggunakan rumus (Watanabe 1988):

FI (g) = Jumlah pakan awal - Jumlah pakan akhir

\section{Feed efficiency (FE)}

Feed efficiency merupakan pertambahan bobot per jumlah konsumsi pakan per satuan unit. Efisiensi pakan dapat dihitung menggunakan rumus berikut ini (Effendie 2002).
FE $(\%)=$ Pertambahan bobot ikan hidup $\times 100$ Jumlah konsumsi pakan $(\mathrm{g})$

\section{Daily growth rate (DGR)}

Daily growth rate merupakan pertambahan bobot ikan perharinya. Perhitungan DGR menggunakan rumus (Effendie 2002):

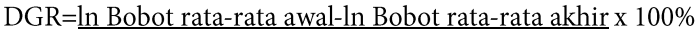
Lama pemeliharaan

\section{Lipid retention (LP)}

Lipid Retention adalah presentase lemak yang disimpan di dalam tubuh per satuan lemak yang dikonsumsi (Watanabe 1988). Rumus yang digunakan untuk menghitung retensi lemak:

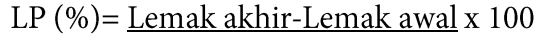
Lemak yang dikonsumsi

\section{Protein retention (PR)}

Protein Retention adalah jumlah protein yang disimpan di dalam tubuh per satuan protein yang dikonsumsi (Watanabe 1988). Berikut rumus yang digunakan untuk menghitung retensi protein:

PR (\%)=Protein awal-Protein akhir $\times 100$ Jumlah protein yang dikonsumsi

\section{Analisis glikogen daging (otot)}

Analisis glikogen daging mengacu pada metode Wedemeyer dan Yasutake (1977).

\section{Analisis organ hati}

Analisis organ hati yang dilakukan adalah uji glikogen hati dan hepatosomatik indek (HSI). Analisis organ hati dilakukan pada awal dan akhir masa pemeliharaan. HSI dapat dihitung dengan menggunakan rumus berikut:

$$
\text { HSI }(\%)=\underbrace{\text { Bobot }}_{\text {Bobot tubuh ikan uji }(\mathrm{g})}
$$

\section{Uji biokimia darah (kadar kolesterol, trigliserida, dan $\mathrm{HDL}$ )}

Analisis kadar kolesterol, trigliserid, dan high density lipoprotein (HDL) dilakukan pada akhir masa budidaya. Analisis kolesterol dilakukan menggunakan metode CHOD-PAP (enzymatic colorimetric test for cholesterol with lipid clearing faktor) dengan kit CHOLESTEROL liquicolor Human mbH Jerman (Trinder 1969). Perhitungan trigliserida juga dilakukan menggunakan CHOP-PAP (enzymatic colorimetric test for triglyserida with lipid clearing faktor) dengan kit TRIGLYSERIDA liquicolormono Human mbH Jerman. Pengukuran HDL menggunakan kit HUMAN CHOLESTEROL liquicolor Precipitant and Standar (Human $\mathrm{mbH}$ Jerman). Analisis biokimia darah dilakukan di UPTD Laboratorium Kesehatan Daerah Bogor.

\section{Analsis proksimat dan fisik kualitas daging}

Analisis proksimat tubuh dan daging ikan nila meliputi protein, lemak, dan kadar air. Pengukuran kadar protein menggunakan metode Kjeldahl dan kadar lemak dengan metode Folch (Takeuchi 1988), pengukuran kadar air dilakukan dengan memasukan sampel ke dalam oven dengan suhu $110^{\circ} \mathrm{C}$ selama 6 jam.

Pengujian fisik meliputi tekstur dan warna. Pengujian dilakukan dengan mengambil 3 ekor ikan pada setiap ulangan, ikan kemudian difillet dengan ketebalan daging dan panjang yang sama. Daging hasil fillet diuji menggunakan alat TA-xt2i, probe yang digunakan $\mathrm{P} / 4$ dengan daya $1,6 \mathrm{~mm} / \mathrm{s}$. Uji warna daging menggunakan Chromameter CR- 200 (Minolta, Osaka, Jepang), penentuan warna berdasarkan nilai $\mathrm{L}^{\star}, \mathrm{a}^{\star}$, dan $\mathrm{b}^{\star}$ (Misimi et al. 2007). 


\section{Analisis Data}

Penelitian ini dilakukan menggunakan rancangan acak lengkap 5 perlakuan dan 4 ulangan. Data yang diperoleh ditabulasi menggunakan MS Excel 2007. Data laju pertumbuhan, kimia hati, proksimat tubuh dan daging ikan, glikogen daging, tingkat tekstur dan warna daging ikan di uji ANOVA menggunakan SPSS 17. Uji lanjut Duncan dilakukan untuk data yang berbeda nyata $(p<0,05)$. Data biokimia darah dianalisis secara deskriptif.

\section{HASIL DAN PEMBAHASAN Kualitas Daging Ikan Nila}

Hasil analisis uji tekstur kekerasan daging ikan nila (Table 1) secara statistikmenunjukkan bahwa perlakuan 15D tidak berbeda nyata dengan kontrol dan 45D. Perlakuan terbaik adalah pemberian tepung daun kayu manis 30 hari sebelum panen (perlakuan 30D). Uji kualitas warna $\mathrm{L}^{\star}$ (lightness), $\mathrm{a}^{*}$ (redness), dan $\mathrm{b}^{*}$ (yelowness) menggunakan chromameter memberikan hasil yang tidak berbeda nyata pada semua perlakuan $(p>0,05)$.

Pemberian tepung daun kayu manis mampu meningkatkan kualitas tekstur daging ikan nila (Table 1). Tekstur filet ikan nila dipengaruhi oleh komposisi kimia dalam tubuh ikan. Kadar lemak daging yang rendah diasumsikan merupakan pengaruh dari senyawa polifenol yang terdapat di daun kayu manis mampu meningkatkan metabolisme lemak (Dairun et al. 2017), sehingga lemak dan karbohidrat dimanfatkan untuk pertumbuhan, sementara protein digunakan untuk menyusun jaringan otot daging ikan. Hal ini terbukti dengan rendahnya retensi lemak pada perlakuan 30D, 45D, dan 60D
(Table 1), sehingga lemak dan karbohidrat dimanfatkan untuk maintenance, sementara protein digunakan untuk menyusun jaringan otot daging ikan.

Kualitas lightness perlakuan 60D memberikan hasil yang lebih tinggi 7,62\% dibanding kontrol. Tingkat redness perlakuan 30D sebesar $77,84 \%$ lebih tinggi dibanding kontrol, namun tingkat yelowness perlakuan 60D lebih tinggi dibanding kontrol. Kualitas warna daging ikan uji yang diberi pakan mengandung daun kayu manis secara statistik tidak berbeda nyata untuk semua perlakuan $(p>0,05)$.

\section{Kinerja Pertumbuhan}

Kinerja pertumbuhan ikan nila selama 60 hari pemeliharaan disajikan pada Table 2. Hasil pengukuran final weight dan protein retention perlakuan $60 \mathrm{D}$ menujukkan hasil yang berbeda nyata dibanding kontrol $(p<0,05)$, namun tidak berbeda nyata pada parameter daily growth rate, feed effisiency dan lipid retention $(p>0,05)$. Feeding intake pakan tidak berbeda nyata semua perlakuan.

Jumlah feed intake (FI) ikan nila pada penelitian memberikan hasil yang tidak berbeda nyata antar perlakuan $(p>0,05)$. Hal ini menunjukkan bahwa palatabilitas pakan perlakuan dapat diterima baik oleh ikan, sama dengan pakan kontrol. Hasil yang sama juga ditemukan oleh penelitian Dairun et al. (2018), yaitu penambahan tepung daun kayu manis sebanyak $1 \%$ tidak memengaruhi jumlah konsumsi pakan pada ikan patin. Penambahan tepung daun kayu manis menunjukkan nilai jumlah konsumsi pakan yang tidak berbeda nyata $(p>0,05)$, namun dapat meningkatkan bobot akhir, laju pertumbuhan harian, dan

Table 1 Fillet texture and fillet color

\begin{tabular}{cccccc}
\hline \multirow{2}{*}{ Parameters } & \multicolumn{5}{c}{ Experimental Day } \\
\cline { 2 - 6 } & Control & $15 \mathrm{D}$ & $30 \mathrm{D}$ & $45 \mathrm{D}$ & $60 \mathrm{D}$ \\
\hline Texture (gf) & $448.9 \pm 33.7^{\mathrm{a}}$ & $450.7 \pm 39.0^{\mathrm{a}}$ & $547.5 \pm 9.1^{\mathrm{b}}$ & $502.1 \pm 44.9^{\mathrm{ab}}$ & $548.8 \pm 20.2^{\mathrm{b}}$ \\
Color & & & & & \\
$\mathrm{L}^{*}$ & $56.7 \pm 1.6^{\mathrm{a}}$ & $60.1 \pm 4.07^{\mathrm{a}}$ & $58.4 \pm 2.01^{\mathrm{a}}$ & $60.5 \pm 3.56^{\mathrm{a}}$ & $61.1 \pm 2.46^{\mathrm{a}}$ \\
$\mathrm{a}^{*}$ & $1.67 \pm 1.00^{\mathrm{ab}}$ & $1.46 \pm 1.19^{\mathrm{ab}}$ & $2.97 \pm 0.82^{\mathrm{b}}$ & $2.00 \pm 0.25^{\mathrm{a}}$ & $1.70 \pm 0.79^{\mathrm{ab}}$ \\
$\mathrm{b}^{*}$ & $7.74 \pm 0.70^{\mathrm{a}}$ & $8.01 \pm 0.34^{\mathrm{a}}$ & $8.67 \pm 0.32^{\mathrm{a}}$ & $8.31 \pm 0.95^{\mathrm{a}}$ & $8.39 \pm 1.10^{\mathrm{a}}$ \\
\hline
\end{tabular}

Note: All data were shown as the mean \pm standard deviation. Different superscripts on the same row indicated significant difference. $\mathrm{L}^{*}$ (lightness), $\mathrm{a}^{*}$ (redness), dan $\mathrm{b}^{*}$ (yellowness). 
Table 2 Growth performance during 60 days

\begin{tabular}{cccccc}
\hline \multirow{2}{*}{ Parameters } & \multicolumn{5}{c}{ Experimental Day } \\
\cline { 2 - 5 } & Control & $15 \mathrm{D}$ & $30 \mathrm{D}$ & $45 \mathrm{D}$ & $60 \mathrm{D}$ \\
\hline Initial weight $(\mathrm{g})$ & $601.8 \pm 18.9^{\mathrm{a}}$ & $605.9 \pm 5.6^{\mathrm{a}}$ & $601.1 \pm 4.5^{\mathrm{a}}$ & $606.1 \pm 1.6^{\mathrm{a}}$ & $608.3 \pm 4.2^{\mathrm{a}}$ \\
Final weight $(\mathrm{g})$ & $3615.2 \pm 146.5^{\mathrm{ab}}$ & $3562.9 \pm 190.8^{\mathrm{ab}}$ & $3376.8 \pm 76.0^{\mathrm{a}}$ & $3647.5 \pm 134.1^{\mathrm{bc}}$ & $3854.3 \pm 219.0^{\mathrm{c}}$ \\
Feed intake (g) & $4259.6 \pm 74.6^{\mathrm{a}}$ & $4368.1 \pm 137.5^{\mathrm{a}}$ & $4284.3 \pm 154.6^{\mathrm{a}}$ & $4232.4 \pm 174.7 \mathrm{a}$ & $4222.3 \pm 83.2^{\mathrm{a}}$ \\
$\begin{array}{c}\text { Daily growth rate } \\
\text { (\% day) }\end{array}$ & $2.99 \pm 0.06^{\mathrm{ab}}$ & $2.95 \pm 0.10^{\mathrm{a}}$ & $2.88 \pm 0.05^{\mathrm{a}}$ & $2.99 \pm 0.06^{\mathrm{ab}}$ & $3.08 \pm 0.08^{\mathrm{b}}$ \\
& & & & $72.0 \pm 4.7^{\mathrm{ab}}$ & $76.9 \pm 5.2^{\mathrm{b}}$ \\
Feed efficiency (\%) & $70.7 \pm 2.8^{\mathrm{ab}}$ & $67.8 \pm 6.4^{\mathrm{a}}$ & $64.8 \pm 2.9^{\mathrm{a}}$ & $38.8 \pm 6.3^{\mathrm{ab}}$ & $44.0 \pm 6.3^{\mathrm{b}}$ \\
$\begin{array}{c}\text { Protein retention } \\
(\%)\end{array}$ & $35.9 \pm 1.4^{\mathrm{a}}$ & $35.7 \pm 3.0^{\mathrm{a}}$ & $35.3 \pm 4.0^{\mathrm{a}}$ & & \\
& & & & & \\
Lipid retention & $89.9 \pm 2.6^{\mathrm{b}}$ & $80.7 \pm 3.2^{\mathrm{ab}}$ & $78.1 \pm 11.5^{\mathrm{a}}$ & $75.9 \pm 5.01^{\mathrm{a}}$ & $82.2 \pm 5.3^{\mathrm{ab}}$ \\
$(\%)$ & & & & \\
\hline
\end{tabular}

Note: All data were shown as the mean \pm standard deviation. Different superscripts on the same row indicated significant difference.

retensi protein masing-masing sebesar $6 \%$, $3,01 \%$, dan $22,42 \%$ dibanding kontrol. Hal ini sesuai dengan penelitan Setiawati et al. (2014) pemberian tepung daun kayu manis dengan dosis $1 \%$ mampu meningkatkan pertumbuhan ikan patin. Peningkatan bobot akhir diduga akibat dari senyawa sinamaldehid yang terdapat di daun kayu manis. Menurut Guo et al. (2017) sinamaldehid mampu meningkatkan aktivitas insulin pada mencit. Insulin merupakan hormon yang berperan penting dalam pengambilan glukosa. Glukosa hasil pencernaan karbohidrat kemudian diserap ke dalam aliran darah dan selanjutnya digunakan sebagai energi untuk pertumbuhan dan berbagai aktivitas metabolisme lainnya.

Pertumbuhan ikan nila ditandai dengan meningkatnya bobot akhir sejalan dengan meningkatnya laju pertumbuhan dan retensi protein ikan nila. Sinamaldehid daun kayu manis juga memiliki kemampuan untuk mengaktifkan insulin-like growth factor (IGF1) yang mampu meningkatkan biosintesis protein dan kolagen dalam jaringan tubuh (Takasao et al. 2012).

Daun kayu manis juga mengandung oleoresin yang berfungsi sebagai antijamur dan antioksidan (Singh et al. 2007) sehingga ikan tetap sehat dan energi yang diperoleh dari makanan dapat dipergunakan sepenuhnya untuk kebutuhan dasar dan pertumbuhan. Sabitha et al. (2014) menyatakan bahwa antioksidan mampu meningkatkan sistem kekebalan tubuh, menjaga fisiologi sel tetap normal, mengurangi paparan radikal bebas sehingga mengurangi kerusakan sel. Efisiensi pakan pada perlakuan 60D meningkat 6,83\% dibanding kontrol $(p>0,05)$ meskipun hasil uji stasistik menunjukkan hasil yang tidak berbeda nyata. Efisiensi pakan menunjukkan bahwa pakan pada perlakuan tersebut dapat dimanfaatkan dengan baik oleh ikan nila untuk pertumbuhan.

\section{Kimia Hati}

Berdasarkan hasil analisis kimia hati ikan nila, glikogen hati perlakuan kontrol menujukkan nilai yang lebih rendah dibanding perlakuan lainnya, namun nilai HSI pakan kontrol memberikan nilai yang lebih tinggi (Table 3).

Nilai glikogen hati pada Table 3 menunjukkan bahwa pada penambahan tepung daun kayu manis berbeda nyata dibanding kontrol $(p<0,05)$. Glukosa berlebih yang tidak dimanfaatkan akan tersimpan di dalam otot dan hati dalam bentuk glikogen sebagai cadangan energi. Nilai glikogen hati yang tinggi menunjukkan besaran persediaan energi yang tersimpan di dalam hati. Glikogen menjadi simpanan energi jangka pendek yang akan digunakan dengan cepat, jika persediaan energi utama habis (Setiawati et al. 2015).

Hati memiliki peran penting dalam mempertahankan kondisi normal glukosa darah dengan menyimpan glukosa sebagai glikogen (Tella et al. 2019). Hormon yang mengatur proses tersebut adalah insulin dengan mengurangi laju glikogenolisis dan meningkatkan serapan glukosa yang 
Table 3 Analysis of tilapia liver

\begin{tabular}{cccccc}
\hline \multirow{2}{*}{ Parameters } & \multicolumn{5}{c}{ Experimental Day } \\
\cline { 2 - 6 } & Control & $15 \mathrm{D}$ & $30 \mathrm{D}$ & $45 \mathrm{D}$ & $60 \mathrm{D}$ \\
\hline $\begin{array}{c}\text { Glycogen } \\
\left(\mathrm{mg} \mathrm{g}^{-1}\right)\end{array}$ & $0.31 \pm 0.00^{\mathrm{a}}$ & $0.33 \pm 0.01^{\mathrm{b}}$ & $0.35 \pm 0.01^{\mathrm{c}}$ & $0.35 \pm 0.00^{\mathrm{c}}$ & $0.35 \pm 0.00^{\mathrm{c}}$ \\
HSI (\%) & & & & & \\
& $1.74 \pm 0.17^{\mathrm{b}}$ & $1.52 \pm 0.22^{\mathrm{ab}}$ & $1.50 \pm 0.08^{\mathrm{ab}}$ & $1.34 \pm 0.39^{\mathrm{a}}$ & $1.32 \pm 0.23^{\mathrm{a}}$ \\
\hline
\end{tabular}

Note: All data were shown as the mean \pm standard deviation. Different superscripts on the same row indicated significant difference. HSI (hepatosomatic indeks).

selanjutnya mengonversi glukosa menjadi glikogen (Edgerton et al. 2001). Kadar HSI ikan nila menunjukkan hasil yang lebih rendah daripada kontrol (Table 3). Kadar HSI pada filet ikan hasil perlakuan yang diberi pakan dengan tambahan tepung daun kayu manis menunjukkan rendahnya lemak yang terdapat di hati. Setiawati et al. (2016) menyebutkan bahwa pengukuran kadar HSI hati memberikan informasi tentang penimbunan lemak di hati.

\section{Nilai Nutrien Tubuh dan Daging Ikan Nila}

Hasil uji nutrien tubuh ikan nila menunjukkan nilai protein antar perlakuan meningkat dibanding kontrol, namun tidak berbeda nyata $(\mathrm{p}>0,5)$ (Table 4). Kadar lemak dan kadar air menurun pada semua perlakuan dibanding kontrol. Nilai protein, lemak dan kadar air paling baik ditunjukkan pada perlakuan $60 \mathrm{D}$, walaupun pada nilai kadar air tidak memberikan pengaruh yang berbeda nyata antar perlakuan. Nilai nutrien daging menunjukkan nilai protein dan lemak berbeda nyata dibanding kontrol $(\mathrm{p}<0,05)$ dan tidak berbeda nyata untuk kadar air $(p>0,05)$. Kecukupuan energi yang berasal dari karbohidrat dan lemak mengakibatkan protein hanya digunakan untuk pertumbuhan. Fenomena ini disebut dengan protein sparing effect (NRC 2011). Nilai kadar air perlakuan yang diberi tambahan tepung daun kayu manis juga menunjukkan hasil yang lebih rendah dibanding kontrol.

\section{KESIMPULAN}

Pemberian pakan mengandung daun kayu manis selama periode waktu 30 hari sebelum panen mampu meningkatkan kualitas kekerasan daging, namun kinerja pertumbuhan yang lebih baik diperoleh pada pemeliharaan 60 hari.

\section{DAFTAR PUSTAKA}

Ahmad MH, Mesallamy AMDE, Samir F, Zahran F. 2011. Effect of cinnamon (Cinnamomum zeylanicum) on growth performance, feed utilization, wholebody composition, and resistance to Aeromonas hydrophila in nile tilapia.

Table 4 Whole body and fillet tilapia nutrient

\begin{tabular}{cccccc}
\hline \multirow{2}{*}{ Parameters } & \multicolumn{5}{c}{ Experimental Day } \\
\cline { 2 - 5 } & Control & $15 \mathrm{D}$ & $30 \mathrm{D}$ & $45 \mathrm{D}$ & $60 \mathrm{D}$ \\
\hline Whole body & & & & \\
Protein (\%) & $15.4 \pm 0.4^{\mathrm{a}}$ & $16.0 \pm 0.8^{\mathrm{a}}$ & $16.1 \pm 0.5^{\mathrm{a}}$ & $16.4 \pm 1.5^{\mathrm{a}}$ & $17.0 \pm 1.6^{\mathrm{a}}$ \\
Lipid(\%) & $6.09 \pm 0.06^{\mathrm{c}}$ & $5.91 \pm 0.16^{\mathrm{bc}}$ & $5.82 \pm 0.13^{\mathrm{b}}$ & $5.56 \pm 0.22^{\mathrm{ab}}$ & $5.53 \pm 0.23^{\mathrm{a}}$ \\
Water content (\%) & $74.8 \pm 2.7^{\mathrm{b}}$ & $72.8 \pm 0.3^{\mathrm{ab}}$ & $70.8 \pm 2.3^{\mathrm{a}}$ & $70.1 \pm 1.6^{\mathrm{a}}$ & $69.9 \pm 0.8^{\mathrm{a}}$ \\
Tilapia fillet & & & & \\
Protein (\%) & $16.8 \pm 0.2^{\mathrm{a}}$ & $17.4 \pm 0.6^{\mathrm{ab}}$ & $17.9 \pm 0.2^{\mathrm{b}}$ & $18.1 \pm 0.8^{\mathrm{bc}}$ & $18.8 \pm 0.7^{\mathrm{c}}$ \\
Fat (\%) & $2.74 \pm 0.21^{\mathrm{b}}$ & $2.01 \pm 0.12^{\mathrm{a}}$ & $1.88 \pm 0.12^{\mathrm{a}}$ & $1.83 \pm 0.15^{\mathrm{a}}$ & $1.85 \pm 0.14^{\mathrm{a}}$ \\
Water content (\%) & $77.5 \pm 0.8^{\mathrm{a}}$ & $76.8 \pm 1.1^{\mathrm{a}}$ & $76.8 \pm 0.9^{\mathrm{a}}$ & $76.7 \pm 1.0^{\mathrm{a}}$ & $76.6 \pm 0.9^{\mathrm{a}}$ \\
Glycogen & $0.31 \pm 0.00^{\mathrm{b}}$ & $0.31 \pm 0.00^{\mathrm{b}}$ & $0.31 \pm 0.00^{\mathrm{b}}$ & $0.30 \pm 0.00^{\mathrm{a}}$ & $0.30 \pm 0.00^{\mathrm{a}}$ \\
$(\mathrm{mg} / 100 \mathrm{~mL})$ & & & & & \\
\hline
\end{tabular}

Note: All data were shown as the mean \pm standard deviation. Different superscripts on the same row indicated significant difference. 
Journal of Applied Aquaculture. 23: 289298.

Dairun S, Setiawati M, Suprayudi MA, Utomo NBP. 2017. Penggunaan daun Cinnamomum burmannii dan kepala udang dalam pakan terhadap kinerja pertumbuhan ikan patin Pangasianodon hypopthalmus. Jurnal Akuakultur Indonesia. 17(1): 87-93.

Edgerton DS, Cardin S, Emshwiller M, Neal D, Chandramouli V, Schumann WC, Landau BR, Rossetti L, Cherrington AD. 2001. Small increases in insulin inhibit hepatic glucose production solely caused by an effect on glycogen metabolism. Diabetes. 50(8): 872-1882.

Effendie MI. 2002. Biologi Perikanan. Yogyakarta (ID). Yayasan Pustaka Nusantara.

[FAO] Food and Agriculture Organization. 2018. Globe fish-a quarterly update on world seafood market the third edition. Rome (IT): Food and Agriculture Organization.

GAR. 2015. Inside the United States-the fish and seafood trade. Canada (CA): GAR.

Guo X, Sun W, Huang L, Wu L, Hou Y, Qin L, Liu T. 2017. Effet of cinnamaldehyde on glucose metabolisme and vessel function. Medical Science Monitor. (23): 3844-3853.

Jusadi D, Hutama AA, Nurhayati T, Wasjan, Vinasyiam A. 2016. Growth performance and flesh quality of common carp, Cyprinus carpio feeding on the diet supplemented with cinnamon (Cinnamommum burmannii) leaf. AACL Bioflux. 9(5):937-943

Khazanah LU, Anadhito BK, Uyun Q, Utami R, Manuhara GJ. 2017. Optimasi proses ekstraksi dan karakterisasi oleoresin daun kayu manis (Cinnamomum burmannii). Indonesian Journal of Essential Oil. 2(1): 20-28.

Laheng S, Setiawati M, Jusadi D, Suprayudi MA. 2016. Evaluasi pemberian ekstrak daun kayu manis Cinnamomum burmannii pada pakan terhadap kinerja pertumbuhan dan kualitas daging ikan patin Pangasianodon hypophthalmus. Jurnal Pengolahan Hasil Perikanan Indonesia. 19(1): 36-43.
Misimi E, Mathiassen JR, Erikson U. 2007. Computer vision-based sorting of atlantic salmon Salmo salar fillets according to their color level. Journal of Food Science. 72(1): 30-35.

[NRC] National Academies Press. 2011. Nutrient Requirements of Fish and Shrimp., Washington DC. (USA): National Academies Press.

Sabitha K, Venugopal B, Rafi MD, Ramana KV. 2014. Role of antioxidant enzymes in glucose and lipid metabolism in association with obesity and type 2 diabetes. American Journal of Medical Sciences and Medicine. 2(1): 21-24.

Setiawati M, Jusadi D, Marlinda S, Syafruddin D. 2014. Pemberian daun kayu manis Cinnamomum burmannii dalam pakan terhadap kinerja pertumbuhan dan komposisi nutrien tubuh ikan patin Pangasius hypopthalmus. Jurnal Ilmu Petanian Indonesia. 19(2): 80-84.

Setiawati M, Sakinah A, Jusadi D. 2015. Evaluasi pertumbuhan dan kualitas daging Pangasianodon hypopthalmus yang diberi pakan mengandung daun Cinnamomum burmannii. Jurnal Akuakultur Indonesia. 14(2): 171-178.

Setiawati M, Jusadi D, Rolin F, Vinasyiam A. 2016. Evaluasi pemberian ekstrak daun kayu manis Cinnamomum burmannii pada pakan terhadap kandungan lemak daging ikan patin Pangasianodon hypopthalmus. Jurnal Akuakultur Indonesia. 15(2): 132-138.

Setiawati M, Dairun S, Suprayudi MA, Utomo NBP. 2017. Pemanfaatan daun kayu manis dan tepung kepala udang sebagai peningkat kualitas daging ikan patin. Jurnal Pengolahan Hasil Perikanan Indonesia. 21(1): 1-9.

Singh G, Maurya S, Lamposa MP, Catalan CAN. 2007. A comparison of chemical, antioxidant and antimicrobial studies of cinnamon leaf bark volatile oils, oleoresins and their contituents. Food and Chemical Toxicology. 45(9): 1650-1661.

Takasao N, Tsuji-Naito K, Ishikura S, Tamura A, Akagawa M. 2012. Cinnamon extract promote type collagen biosynthesis via activation pf IGF-I signaling in human 
dermal fibroblats. Journal of Agricultural and Food Chemistry. 60(5): 1193-1200.

Takeuchi T. 1988. Laboratory work chemical evaluation of dietary nutrition. In Watanabe T, ed. Fish Nutrition and Mariculture, JICA Textbook. The general aquaculture corse. Kanagawa international fisheries training center. Japan international coorperation agency (JICA).

Tella T, Masola B, Mukaratirwa S. 2019. The effect of Psidium guanjava aqueos leaft extract on liver glycogen enzymes, hormones sensitive lipase and serum lipid profile in diabetic rats. Biomedicine and Pharmacotherapy. 109: 2441-2446.

Watanabe T. 1988. Fish Nutriotion and Mariculture. Tokyo (JP): Kanagawa International Fish Training Center.

Wedemeyer GA, Yasutake WT. 1977. Clinical Method for The Assessment of The Effect of Environmental Stress on Fish Health., Washington DC (US): Tech. Pap. of the US fish and wildlife serv. 